\title{
The Learning of Writing Experimental Reports by Using Scientific Approach of Early Class Students in Elementary School
}

\author{
Rizky Amelia \\ Elementary School Teacher Education \\ Faculty of Education \\ Universitas Negeri Padang \\ rizkyamelia656@yahoo.com
}

\begin{abstract}
This research aimed to explain the implementation of experimental writing report by using scientific approach on the third grade students at SDN 15 Ulu Gadut, Pauh sub-district, Padang city. This research used qualitative approach. Data were collected by Primary Student Observation Sheet (PSOS). Data were analyzed by inductive analysis. Research subjects consisted of 36 students of SDN 15 Ulu Gadut, Pauh sub-district, Padang city. The results showed that the implementation of the scientific approach in learning to write experimental report motivated the students to learn how to write report in which the data were acquired from the real objects and phenomena happened, students felt challenged exploring of their curiosity about natural phenomena, the activities rose up the student about writing, and students interested in writing because they published the results of their experiments in written form.
\end{abstract}

Keywords-writing report; scientific.

\section{INTRODUCTION}

Writing skills is an important language skill for elementary school students [1][2]. Writing skills must be owned by students started from elementary school level, without adequate writing skills from an early age, children will experience learning difficulties in the future [3]. With regard to the functioning of writing skills, Morsy explain that in modern life, writing skills are definitely indispensable. It is not excessive if we say that writing skills are characteristic of a well educated person or nation [4]. The same statement is also expressed by Intitute of Education Sciences (IES), The students who develop strong writing skills at an early age acquire a valuable tool for learning, communication, selfexpression, and help them succeed in school and society [5].

Writing are productive and expressive activities [6] Writing includes aspects of language activities that are considered as a difficult matter. Many students complained in primary and secondary education, college students also complained about the difficulty of writing [6][7][8][9][10]. The consequences of the complaint eventually became public opinion, that writing was difficult.

Another fact shows that the writing culture of Indonesian society is still less than satisfactory [11]. Indonesian children ability to write is ranked at the bottom when compared with Asian children [12]. Research conducted by the IEA Study of Writing Literacy concluded that the writing ability of elementary school children in Indonesia is still very low [5].

The low writing culture is caused by the weakness of the writing system in schools [13][14][15][16]. The fact that learning writing gets less proper attention [15][17][18][19]. Learning to write as one of the aspects in learning Bahasa Indonesia less handled seriously. In general, Indonesian students never get the material how to write proper. Students and teachers usually emphasize lesson activities on mastery of material that leads to student success in national final exams [20][20]. In fact, learning to write is a complex and difficult set of processes that requires an obvious learning methodology framework at all stages of learning [21]. According to Nunan, writing skills that are coherent, fluent, and broad, are the most difficult skills to learn amongst language skills. Thus, that learning to write in schools should get adequate attention [22]. 
One of the writing skills in elementary school is writing an experimental report. Students assigned to experiment on a particular matter then must submit a report on the matter assigned to it. Research activities and experiments should be published, as it will prove the authenticity of the data and experimental results [23].

But the learning activities do not done as expected. Students are less aware about the purpose of learning to write an experimental report. Students believe writing a test report is a command of the teacher to be implemented and without knowing the purpose of writing a test report that they are doing. This fact is in contrast to the results of research by Graham et al. Published in the Institute of Education Sciences, students should understand the purpose of each genre so that they can select the genre best suited to their writing task [24]. That states that students must understand the purpose of each writing types so that they can determine the most appropriate type of writing due their writing assignment.

During that period, learning to write a report is more emphasized on the results in the form of writing, not on what should be done when students write. Students directly practice writing without learning how to write. The teacher asked students to write according to the basic competencies in the curriculum. Once completed, the student's writing is collected, corrected, and assessed by the teacher. This activity is constantly done which resulted in students feel saturated and not enthusiastic in following the writing lesson [16].

To optimize the students ability, especially in the field of writing the experimental report skills, learning approach is needed that emphasizes in the learning activities and creativity of the students. The effort to improve the effectiveness of learning to write using the scientific approach that emphasizes the importance of the learning process for students.

The superiority of the scientific approach is enabling students to become accustomed to methodological thinking. And by using this approach in learning will develop the ability to write reports for students, because students have understood how to collect information and process information from experiments that have been done.

\section{METHODS}

This research is conducted by using qualitative approach and this is a kind of descriptive research. This is consistent with Parkinson's and Drislane's, [Qualitative research is] research using methods such as participant observation or case studies which result in a narrative, descriptive account of a setting or practice [25]. Qualitative approach is a method of approach in the form of observation and case studies with results in the form of narrative, descriptive, and setting or practice. The use of qualitative research is due to the inductive nature of this research, namely the concept development based on data obtained. Qualitative research reports are organized in the form of narratives that are creative and profound and show their natural characteristics. Arikunto states that in descriptive research the researcher did not manipulate or give a certain treatment to the object of research, all activities or events running as it is [26].

Data were collected by Primary Student Observation Sheet (PSOS). Data were analyzed by inductive analysis. Research subjects consisted of 36 students of SDN 15 Ulu Gadut, Pauh sub-district, Padang city.

\section{RESULTS}

Learning activities using the scientific approach requires students to write actively a test report well [27]. Therefore, teachers need to guide students in the learning process. Teachers will guide students according to the steps of the Scientific approach, the activities undertaken at this stage refer to Hosnan's opinion where the scientific approach step includes five steps:

\section{a) Observing}

The first step in writing an experimental report is that the teacher shows pictures relating to the type of doctor's activity. Descriptors or findings that emerged from the teacher's aspect that they have displayed images related to the material in front of the class and asked students to observe it. In addition, the teacher has reminded students not to make a fuss when looking at the picture and the teacher has tried to make the students interested to observe the picture.

Descriptor or findings that arise from aspects of students are: Students have paid attention to teachers displaying images related to the material and observing images displayed by teachers and images on display have been interesting for students.

b) Asking question

In this activity, the teacher lures students to ask about stethoscopes. Descriptors or findings that arise from the aspect of the teacher is the teacher who has asked students to point hands for those who want to ask questions, and gave opportunity to other students to ask questions in turn. Descriptors or findings that arise from the student's aspect 
such as students have been able to ask questions, students spontaneously point their hands when they want to ask questions, and students look enthusiastic to ask questions and students are given the opportunity to ask questions in turn.

\section{c) Experimenting}

In the experimenting activities, students experiment on making a simple stethoscope. Descriptor or findings that emerged from the teacher's aspect of the teacher who has given explanation about the experiment will be done by the students, the teacher has been paying attention to students doing the experiment, and the teacher has guided the students in experimenting. And teachers have reminded students to work with group members in experimenting.

Descriptors or findings that arise from aspects of students such as students who pay attention to the teacher's explanation of the experiment will be done, students have received guidance in the experiment, students are working with group members in experimenting, and students have done the experiment carefully.

\section{d) Reasoning}

In the activity of report writing, students note the important things while doing the experiments such make a simple stethoscope. Descriptors or findings that arise from the teacher's aspect that is the teacher who has guided the students to record important things while doing the experiments and have paid attention to the students in noting the important things while the experiment. Besides, the teacher has reminded the students not to be fuss when they recorded the important things as well as the teacher has guided the students to discuss among the group members to record the important things during the experiment.

Descriptors or findings that arise from the aspect of students such as students who have received guidance from teachers to record important things during the experiment, students have discussions between group members to record important things while doing the experiment and students have recorded the important things when Experiment. But students make a fuss when recording the important things.

\section{e) Shaping nets}

In this stage, students write an experimental report making a simple stethoscope. Descriptor or findings that emerged from the teacher's aspect of the teacher who has given a briefing in writing the experiment report, the teacher asked students to write a trial report coherently, and the teacher guided the students in the trial report. And teachers reminded students not to disturb friends while writing reports.

Descriptors or findings that arise from the student aspect of the students listening to the briefings from the teacher in writing the experiment report, the student has written the experimental report coherently, and the students get guidance from the teacher in the trial report reporting, and the students do not disturb the friend while writing the experiment report.

\section{DISCUSSION}

Implementation of the learning in writing report using scientific approach in Elementary School found things as follows:

\section{a) Observing}

The first step in writing an experimental report that students make direct observations on the object or phenomenon to be written so that students get facts in the form of objective data which is then analyzed according to the level of student development. The statement is in accordance with Padilla's opinion, observing - using the senses to gather information about an object or event [28]. That states that observing activity is done by using the senses to gather information about an object or event. In addition, according to Ostlund, that Science begins by observing objects and events; This observation will lead to ask a question [29]. By observing, the students feel challenged exploring their curiosity about the challenging phenomenon and natural secrets [30][31].

In addition, teachers also ask students to observe samples of correct experimental reports and compare experimental reports they have made previously with experimental reports that teachers make in accordance with the correct trial report criteria.

\section{b) Asking question}

In this activity, students ask questions about information that is not understood from what is observed or questions to obtain additional information about what is observed (starting from factual questions to hypothetical questions). Competencies developed are creativity, curiosity, the ability to formulate questions to form the critical thinking necessary for intelligent life and lifelong learning [32]. This is in accordance with the opinion of Ostlund, that the important thing in the method of science is the ability to ask the right questions and conduct experiments relevant to the question 
[29]. Furthermore, writing and Scientific emphasize the same intellectual skills and are concerned with critical thinking skills [33]. It is explained that writing and Scientific emphasize the same intellectual skills and both are related to critical thinking skills.

\section{c) Experimenting}

In experimenting activities, teachers (1) involve students looking for broad and deep information about the topic or theme of the material to be learned by applying the principles of learning from various sources, (2) using various learning approaches, instructional media, and other learning resources, (3) Facilitate the interaction between students, as well as students with teachers, the environment, and other learning resources, (4) actively involve students in learning activities, and (5) facilitate students in laboratory or field experiments.

In this step, students collect data from the object or experimental phenomenon to be written as report. Students record each try activity performed along with the results obtained. This activity motivates students to learn to write significantly because they collect the data themselves from the object or experiment phenomenon to be written report [34][35]. According to Piaget, further studies of experimental abilities are closely related to thinking ability [28]. This is because it collects the data itself from the object or experimental phenomenon to which the report will be written.

Teacher has prepared the tools used in experimenting with simple stethoscopes: funnel, thick cardboard rolls, masking tape, and scissors. Then the students start to make a simple stethoscope. Students are asked to record important things while experimenting with a stethoscope. Alternately the students tried the stethoscope that had been made to hear the heartbeat.

\section{d) Reasoning}

In the activity of writing the report, students perform the activities of reasoning through discussion, which is discussing the results of experiments that have been done [36]. Student analysis activity is processing data, information, facts that have been recorded and collected in activity of experiment to be sentences that have good cohesion and coherence [37]. Sentences in writing reports should fulfil these things : (1) short, concise, and clear, (2) using simple and understandable language; (3) avoiding the use of terms that are confusing and poorly understood by the public; (4) concerning about ethics, aesthetics, and language should be logic, and (5) using active sentences instead of passive sentences [37][38].

\section{e) Shaping nets}

In this phase, students required to describe their comprehension about a concept whether oral or written. Activities can be done is making the reports of experimental results [39]. Then students asked to publish their experiment results in several media. This activity can encourage the students interest in writing because they can publish they experimental result in writing [39][40].

Experimental reports are arranged systematically in the order of events or experimental activities. The language used in writing the report should be a good language (simple and straightforward), clear (short and easy to understand), and well organized [41]. Then the students write an experimental report of making a simple stethoscope and make conclusions about the stethoscope relationship with nature of sound. Students are reminded to pay attention to systematic writing, completeness of report content and neatness of writing. In the activities of writing a report, students get things, namely as follows:

First, students have the motivation to write because teachers provide enough time for students to write [40][42]. Providing adequate time for students to write is one of the key elements in producing an effective writing from students. Because the latest survey of elementary school teachers published in the Institute of Education Sciences, states that students spend less time writing in school every day [24]. Students need instructional time dedicated to learning the skills and strategies needed to be an effective writer, as well as the time to practice what they learn. Time for writing exercises can help students gain confidence in their writing abilities [42]. As teachers observe how students write, they can identify difficulties and help students by learning and applying the writing process [42].

Second, the students know the purpose of the report writing activity that they do. Teachers should start teaching students that there are different goals in writing and different types of writing that can help students achieve their writing goals [24]. The purpose of writing a report is as a publication, meaning that however great the results of the experiment, it will not be complete without producing a publication [43]. The experimental activity should be published, as it will prove the authenticity of the data and experimental results [23].

Third, students are motivated to learn how to write in real terms as they collect data from the object or experimental 
phenomenon to be written in the report. Student involvement in science-based learning activities provides learning with an engaging experience for students when they think and write [33]. A study of the relationship between report writing and sciences experiences shows that when children write their own experimental results, their writing scores improve significantly [29].

Fourth, this learning can improve students' interest in writing because they can publish the results of their experiments in written form. Because someone who is experimenting has an obligation to present an experiment in writing so that the reader can understand the experiments performed [29].

\section{CONCLUSION AND SUGGESTION}

From the exposure of the research and discussion above, the conclusion that can be drawn from this research is the implementation of learning to write experiment report in elementary school based on learning experience by using scientific approach. The first step is the students make direct observations on the object or phenomenon to be written. Second, students ask questions about information that is not understood from what is observed or questions to get additional information about what is observed. Third, students collect data from the object or experimental phenomenon to be written report. Fourth, students discussed the results of experiments that have been done. And fifth, the students presented their experimental results in the experimental writing study.

Based on the conclusions that have been obtained in this research, the authors propose suggestions to primary school teachers and educational practitioners that scientific approach is worth considering to be one approach of learning model used in writing report in Primary School.

\section{References}

[1] B. McLaughlin, Second language acquisition in childhood: Volume 2: School-age Children. Psychology Press, 2013.

[2] J. Andrews and H. Higson, "Graduate employability, 'soft skills' versus 'hard'business knowledge: A European study," High. Educ. Eur., vol. 33, no. 4, pp. 411-422, 2008.

[3] R. L. Allington and P. M. Cunningham, Schools that work: Where all children read and write. ERIC, 2002.

[4] H. G. Tarigan, Menulis sebagai suatu keterampilan berbahasa. Angkasa, 1986.

[5] W. B. Elley, "How in the world do students read? IEA study of reading literacy.," 1992.

[6] P. Prior, Writing/disciplinarity: A sociohistoric account of literate activity in the academy. Routledge, 2013.
[7] D. Nicol, "From monologue to dialogue: improving written feedback processes in mass higher education," Assess. Eval. High. Educ., vol. 35, no. 5, pp. 501-517, 2010.

[8] S. Graham, "Executive control in the revising of students with learning and writing difficulties.," J. Educ. Psychol., vol. 89, no. 2 , p. $223,1997$.

[9] R. M. Felder and R. Brent, "Navigating the bumpy road to studentcentered instruction," Coll. Teach., vol. 44, no. 2, pp. 43-47, 1996.

[10] D. B. West, Introduction to graph theory, vol. 2. Prentice hall Upper Saddle River, 2001.

[11] E. P. Putra, "Gerakan Menggiatkan Budaya Literal," Media Indones., vol. 31, 2008.

[12] K. Supriyoko, "Pendidikan Masyarakat Multikultural," dalam Kompas, vol. 26, 2004.

[13] A. M. Cohen, The shaping of American higher education: Emergence and growth of the contemporary system. John Wiley \& Sons, 2007.

[14] L. C. Matsumura, G. G. Patthey-Chavez, R. Valdés, and H. Garnier, "Teacher feedback, writing assignment quality, and third-grade students' revision in lower-and higher-achieving urban schools," Elem. Sch. J., vol. 103, no. 1, pp. 3-25, 2002.

[15] S. Graham and D. Perin, "Writing next-effective strategies to improve writing of adolescents in middle and high schools." 2007.

[16] K. Syamsi, "Model perangkat pembelajaran menulis berdasarkan pendekatan proses genre bagi siswa SMP," Litera, J. Penelit. Bahasa, Sastra, dan Pengajarannya, vol. 11, no. 2, pp. 288-297, 2012.

[17] M. Torrance and D. Galbraith, "The processing demands of writing," Handb. Writ. Res., pp. 67-80, 2006.

[18] K. Hyland, "Writing without conviction? Hedging in science research articles," Appl. Linguist., vol. 17, no. 4, pp. 433-454, 1996.

[19] V. W. Berninger, D. T. Mizokawa, and R. Bragg, "Scientific practitioner: Theory-based diagnosis and remediation of writing disabilities," J. Sch. Psychol., vol. 29, no. 1, pp. 57-79, 1991.

[20] J. W. Stigler and J. Hiebert, The teaching gap: Best ideas from the world's teachers for improving education in the classroom. Simon and Schuster, 2009.

[21] P. Knapp and M. Watkins, Genre, text, grammar: Technologies for teaching and assessing writing. UNSW Press, 2005.

[22] D. Nunan, Second Language Teaching \& Learning. ERIC, 1999

[23] S. Sumarsono, "Teknik penulisan laporan," Ed. Pertama, Cetakan Pertama, Penerbit Graha Ilmu, Yogyakarta, 2003.

[24] S. Graham et al., "Teaching Elementary School Students to Be Effective Writers: A Practice Guide. NCEE 2012-4058.," What Work. Clear., 2012.

[25] M. Q. Patton, Qualitative research. Wiley Online Library, 2005.

[26] S. Arikunto and S. Suhardjono, "Penelitian tindakan kelas." Jakarta: Bumi Aksara, 2006.

[27] M. Hosnan, Pendekatan saintifik dan kontekstual dalam pembelajaran abad 21: Kunci sukses implementasi kurikulum 2013. Ghalia Indonesia, 2014.

[28] M. J. Padilla, "Research Matters," Res. Matters - to Sci. Teach., no. The Science Process Skills, 2010.

[29] K. Ostlund, "What the research says about science process skills," Electron. J. Sci. Educ., vol. 2, no. 4, pp. 1-8, 1998.

[30] S. M. Brookhart, How to give effective feedback to your students. ASCD, 2017.

[31] Z. O'Leary, The essential guide to doing your research project. Sage, 2017.

[32] H. J. M. Stokhof, B. De Vries, R. L. Martens, and T. J. Bastiaens, "How to guide effective student questioning: a review of teacher guidance in primary education," Rev. Educ., vol. 5, no. 2, pp. 123 $165,2017$.

[33] M. S. Simon and J. M. Zimmerman, "Science and Writing.," Sci. 
Child., vol. 18, no. 3, pp. 7-9, 1980.

[34] H. Sa'diyah, "IMPROVING STUDENTS'ABILITY IN WRITING DESCRIPTIVE TEXTS THROUGH A PICTURE SERIES-AIDED LEARNING STRATEGY," English Teach., p. 19, 2017.

[35] S. G. Paris, G. M. Olson, and H. W. Stevenson, Learning and motivation in the classroom. Routledge, 2017.

[36] R. E. Simamora, D. R. Sidabutar, and E. Surya, "Improving Learning Activity and Students' Problem Solving Skill through Problem Based Learning (PBL) in Junior High School," Int. J. Sci. Basic Appl. Res., vol. 33, no. 2, 2017.

[37] P. H. Agusditya, I. S. Asri, and I. M. Suara, "The Effect of Scientific Approach Based on Portfolio Assessment towards the Learning Outcomes of Civic Education of the Students Grade V Viewed from the Tendency of Observing Objects on Theme 7 SDN 4 Ubung," J. Educ. Res. Eval., vol. 1, no. 2, pp. 91-99, 2017.

[38] D. Wyse and K. Cowan, The good writing guide for education students. Sage, 2017.

[39] D. C. Montgomery, Design and analysis of experiments. John Wiley \& Sons, 2017.

[40] J. L. Galvan and M. C. Galvan, Writing literature reviews: A guide for students of the social and behavioral sciences. Routledge, 2017.

[41] A. Falavigna, D. De Faoite, M. Blauth, and S. L. Kates, "Basic Steps to Writing a Paper: Practice Makes Perfect," BANGKOK Med. $J .$, vol. 13, no. 1, 2017.

[42] S. Brookfield, Becoming a critically reflective teacher. John Wiley $\&$ Sons, 2017.

[43] C. A. Taylor and J. Stevenson, "Leadership of academic writing development in England: narratives of problems, pragmatism and possibility," Cosmop. Perspect. Acad. Leadersh. High. Educ., p. 91, 2017. 